\title{
The Effect of Resins on Rheological and ageing Characteristics of Bitumen for Pavement
}

\author{
Madi Hermadi ${ }^{1, *}$, Willy Pravianto ${ }^{1}$ \\ ${ }^{1}$ Asbuton Research and Development Division Institute of Road Engineering, Research and Development Agency, Ministry of Public \\ Work and Housing, Indonesia
}

\begin{abstract}
Bitumen consists of thousands of hydrocarbon molecule types with each molecule contributes to the overall bitumen characteristics. Therefore, it is important to identify the influence of each chemical component of bitumen that altogether constructs the bitumen characteristics. This is likely to be completed by evaluating and modifying bitumen components to produce a new type of bitumen with better characteristics. The realistic way to do this is by analysing it in groups or fractions; one group or fraction comprises bitumen molecules with similar characteristics. This paper aims to address this issue by describing the effect of resins on rheological characteristics of bitumen at various ageing process stages. . The materials used in this study were Buton rock asphalt or natural rock asphalt from Buton Island in Indonesia which was from Lawele region and petroleum bitumen penetration grade 80/100 from a refinery in Kemaman Malaysia. The materials were tested to identify their charactheristics and the resins components were also extracted and tested with Corbett method. Each extracted resin (from Buton rock asphalt bitumen and petroleum bitumen) was blended in proportions of $0 \%, 5 \%$, and $10 \%$ with the Kemaman petroleum bitumen as a bitumen medium. The blended bitumen samples were also tested for their rheological characteristics using Dynamic Shear Rheometer. Each sample was tested at five different temperature levels $\left(46^{\circ} \mathrm{C}, 52^{\circ} \mathrm{C}, 58^{\circ} \mathrm{C}\right.$, $64^{\circ} \mathrm{C}$ and $70^{\circ} \mathrm{C}$ ) and at un-aged, artificial short-term aged (RTFOT-aged), and artificial long-term aged (PAV-aged) conditions. The results indicated that the source of resins had a significant value of 0.065 or larger than the 0.05 critical point value. There was no difference in the effect of the experiments using either Buton rock asphalt or petroleum bitumen on the complex shear modulus $\mathrm{G}^{*}$. At fresh condition, there was no effect of adding resins on the bitumen rheological characteristics except for the elastic modulus ( $\left.\mathrm{G}^{\prime}\right)$. However, the effect increased over the RTFOT-ageing and PAV-aging level because of the normal ageing process.
\end{abstract}

Keywords: pavements material, resins, Buton Rock Asphalt, rheological charactheristics, ageing process

\section{Introduction}

Bitumen consists of thousands of hydrocarbon molecule types with each molecule contributes to the overall bitumen characteristics. Therefore, it is important to identify the influence of each chemical component of bitumen that altogether constructs the bitumen characteristics. This is likely to be completed by evaluating and modifying bitumen components to produce a new type of bitumen with better characteristics. However, because bitumen consists of a great number of hydrocarbon molecule types, it can be said that it is impossible to individually analyse the influence of each molecule one by one. The realistic way to do this is by analysing it in groups or fractions; one group or fraction comprises bitumen molecules with similar characteristics. One way to conduct bitumen fractionation was developed by Corbett (1969) of which procedure was standardised as ASTM D 4124. According to Corbett (ibid.), bitumen consists of four molecule fractions, they are asphaltenes, polar aromatics, naphthene aromatics, and saturates. Lesueur (2009) explains that polar aromatics, which is also called resins, consists of aliphatics, naphthenes and aromatics in a multi-ring structure along with sulphur, oxygen and nitrogen compounds. Its colour is black and in the form of semi-solid material with the average molecular weight of around 1,800 g/mol. It is polar and sometimes can be more polar than asphaltenes. Its function in the bitumen structure is as a stabilizer for the asphaltenes. 
Furthermore, a similar explanation is suggested by Hardee (2005) that resins are brown-black, adhesive, shiny solid or semi-solid material which comprises heterogeneous polar aromatics compounds with a small amount of oxygen, nitrogen and sulphur with molecular weights of $800-2,000 \mathrm{~g} / \mathrm{mol}$ and constitutes $15-25 \%$ of the bitumen total weight.

This paper aims to address this issue by describing the effect of resins on rheological characteristics of bitumen at various ageing process stages. In regard to pavement, in particular, rheological characteristics are used to indicate the rutting, cracking and ageing resistances of bitumen at original, short-term and longterm ageing conditions.

\section{Materials and Methods}

The materials used in this study were Buton rock asphalt or natural rock asphalt from Buton Island in Indonesia and petroleum bitumen with the penetration grade of $80 / 100$ from a refinery in Kemaman District in Malaysia. The bitumen of Buton rock asphalt which was deposited in Lawele region was extracted and recovered in accordance with ASTM D 2172 and ASTM D 5404. The characteristics of each material are shown in Table 1 to 3 .

Table 1. Characteristics of Buton Rock Asphalt Bitumen

\begin{tabular}{|c|c|c|c|}
\hline Characteristics & $\begin{array}{c}\text { Test } \\
\text { method }\end{array}$ & $\begin{array}{c}\text { Test } \\
\text { results }\end{array}$ & Specification*) \\
\hline $\begin{array}{c}\text { Penetration at } 25^{\circ} \mathrm{C}, 100 \\
\text { g, } 5 \text { sec; } 0,1 ; \mathrm{mm}\end{array}$ & $\begin{array}{c}\text { ASTM D } \\
5\end{array}$ & 85 & $80-100$ \\
\hline $\begin{array}{c}\text { Ductility at } 25^{\circ} \mathrm{C}, 5 \\
\mathrm{~cm} / \text { minute; } \mathrm{Cm}\end{array}$ & $\begin{array}{c}\text { ASTM D } \\
113\end{array}$ & $>140$ & Min. 100 \\
\hline $\begin{array}{c}\text { Loss on heating } \\
\text { (RTFOT); } \%\end{array}$ & $\begin{array}{c}\text { ASTM D } \\
2872\end{array}$ & 1.53 & Max. 0.8 \\
\hline $\begin{array}{c}\text { Penetration at } 25^{\circ} \mathrm{C}, 100 \\
\text { g, } 5 \text { sec after RTFOT; } \\
\% \text { Original }\end{array}$ & $\begin{array}{c}\text { ASTM D } \\
5\end{array}$ & 65.2 & Min. 47 \\
\hline $\begin{array}{c}\text { Ductility at } 25^{\circ} \mathrm{C}, 5 \\
\text { cm/minute after } \\
\text { RTFOT, } \mathrm{cm}\end{array}$ & $\begin{array}{c}\text { ASTM D } \\
113\end{array}$ & $>140$ & Min. 75 \\
\hline $\begin{array}{c}\text { Solubility in } \mathrm{C}_{2} \mathrm{HCl} \\
\text { H; } \%\end{array}$ & $\begin{array}{c}\text { ASTM D } \\
2042\end{array}$ & 99.2 & Min. 99 \\
\hline Water content; $\%$ & $\begin{array}{c}\text { ASTM D } \\
1461\end{array}$ & & 0.00 \\
\hline
\end{tabular}

\footnotetext{
*) The specification refers to ASTM D 946
}

Table 2. Characteristics of Buton Rock Asphalt Raw Materials

\begin{tabular}{|c|c|c|}
\hline $\begin{array}{c}\text { Lawele-BRA } \\
\text { Characteristics }\end{array}$ & Test Method & $\begin{array}{c}\text { Test } \\
\text { results }\end{array}$ \\
\hline Bitumen content; \% & $\begin{array}{c}\text { ASTM D } \\
2172\end{array}$ & 35.3 \\
\hline Water content; \% & $\begin{array}{c}\text { ASTM D } \\
1461\end{array}$ & 11.8 \\
\hline $\begin{array}{c}\text { Penetration of extracted } \\
\text { bitumen at 25ㄷ, 100g, } \\
\text { 5 sec; dmm }\end{array}$ & ASTM D 5 & 183 \\
\hline $\begin{array}{c}\text { Loss on heating of dry } \\
\text { B.R.A. (TFOT); \% }\end{array}$ & $\begin{array}{c}\text { ASTM D } \\
1754\end{array}$ & 6.1 \\
\hline
\end{tabular}

Table 3. Characteristics of Buton Rock Asphalts Raw Materials

\begin{tabular}{|c|c|c|c|}
\hline $\begin{array}{c}\text { Petroleum Bitumen } \\
\text { Characteristics }\end{array}$ & Test method & $\begin{array}{c}\text { Test } \\
\text { results }\end{array}$ & Specification*) \\
\hline Penetration at $25 \mathrm{C}, 100$ & \multirow{2}{*}{ ASTM D5 } & \multirow{2}{*}{95} & \multirow{2}{*}{$80-100$} \\
\hline $\mathrm{g}, \quad 5 \mathrm{sec} ; \mathrm{dmm}$ & & & \\
\hline $\begin{array}{c}\text { Ductility at } 25^{\circ} \mathrm{C} \\
5 \mathrm{~cm} / \text { minute; } \mathrm{cm}\end{array}$ & ASTM D113 & $>140$ & Min. 100 \\
\hline $\begin{array}{l}\text { Loss on heating } \\
\text { (RTFOT); \% }\end{array}$ & $\begin{array}{l}\text { ASTM } \\
\text { D2872 }\end{array}$ & 0.035 & Max.0.8 \\
\hline Penetration at $25 \mathrm{C}, 100$ & & 760 & \\
\hline $\begin{array}{cc}\mathrm{g}, & 5 \mathrm{sec} \text { after } \\
\text { RTFOT, } \% \text { Original }\end{array}$ & ASTM D5 & 76.9 & Min. 47 \\
\hline $\begin{array}{c}\text { Ductility at } 25^{\circ} \mathrm{C}, 5 \\
\mathrm{~cm} / \mathrm{min} \text {, after RTFOT; } \\
\mathrm{cm}\end{array}$ & ASTM D113 & $>140$ & Min. 75 \\
\hline Solubility in $\mathrm{C}_{2} \mathrm{HCl}_{3} ; \%$ & $\begin{array}{l}\text { ASTM } \\
\text { D1461 }\end{array}$ & 99.5 & Min. 99 \\
\hline Water content; \% & $\begin{array}{l}\text { ASTM } \\
\text { D2042 }\end{array}$ & 0.0 & - \\
\hline
\end{tabular}

*) The specification refers to ASTM D 946

Resins from the Buton rock asphalt and petroleum bitumen were extracted based on the ASTM D 4124 testing procedures. The extraction process of this method is illustrated in Figure 1.

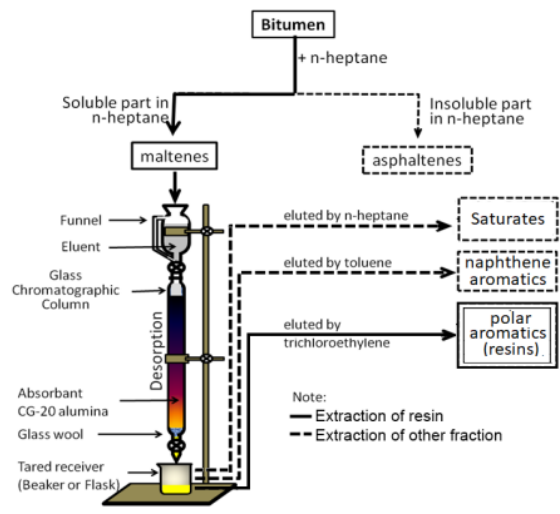

Fig. 1 Separating bitumen components based on ASTM D 4124 Procedures (Hermadi, 2012) 
Based on ASTM D 4124, the bitumen sample was dissolved in n-heptane. Then, the solution was filtered to remove the asphaltenes. The maltenes solution which consisted of saturates, naphthene aromatics and resins, was then poured into a chromatographic column to be absorbed by CG-20 Alumina. After the saturates and the naphthene aromatics were eluted by $n$-heptane and toluene, the resins fraction was eluted by trichloroethylene and recovered by evaporating the solvent by heating it at $105^{\circ} \mathrm{C}$.

Next, each extracted resin (from Buton rock asphalt and petroleum bitumen) was blended in proportions $(0 \%, 5 \%$, and $10 \%)$ with the Kemaman petroleum bitumen as a medium. The blended bitumen was then tested for rheological characteristics identification using Dynamic Shear Rheometer or DSR (ASTM D 7175). The DSR test was utilised to the complex shear modulus $\mathrm{G}^{*}$, and the phase angel $\delta$ of the bitumen. The two parameters are commonly used in Superpave Performance Grade Specification to determine the rutting and fatigue resistance of bitumen binder. The specification has been standardised as the standard specification for performance grade asphalt binder ASTM D 6373.

Each sample was tested at five different levels of temperature $\left(46^{\circ} \mathrm{C}, 52^{\circ} \mathrm{C}, 58^{\circ} \mathrm{C}, 64^{\circ} \mathrm{C}\right.$ and $\left.70^{\circ} \mathrm{C}\right)$ and at un-aged, artificial short-term aged (RTFOT-aged, ASTM D 2872), and in artificial long-term aged (PAVaged, ASTM D 6521) conditions. This range of temperature levels was equal to the range of maximum bitumen performance grade temperature levels (ASTM D 6373).

Superpave chose $G^{*} / \sin [\delta]$ parameter as the rutting factor to indicate the level of rutting resistance of bitumen because this parameter determines the work dissipated per load cycle at a constant stress related to the behaviour of asphalt [4]. Parameter $G^{*} \sin [\delta]$ was selected as the fatigue factor since this parameter determines the work dissipated per load cycle at a constant strain which was considered relevant to the fatigue behaviour of the asphalt under a constant strain condition [4]. It is worth noting that $G^{*} \sin [\delta]$ is actually equal to the viscous modulus G".

The test results were assumed as normal and homogenous because the experiment was conducted in a homogenous environment where the level factors interaction was controlled.

The relationship of the resins content with the rheological characteristics of bitumen blend was statistically evaluated using analysis of variants (ANOVA), and analysis of regression. ANOVA was used to evaluate the significant effect of factors on variants, and analysis of regression was used to determine the coefficient of regression. Five factors (independent variables) used are exhibited in Table 4.
Table 4. Factors and the Level Factors

\begin{tabular}{|l|l|}
\hline \multicolumn{1}{|c|}{ Factor } & \multicolumn{1}{c|}{ Level factor } \\
\hline Source of resins & $\begin{array}{l}\text { BRA-bitumen, and } \\
\text { petroleum bitumen }\end{array}$ \\
\hline Method of extracting resins & Corbett method \\
\hline Percentage of resins & $0 \%, 5 \%$, and $10 \%$ \\
\hline Test temperature & $\begin{array}{l}46^{\circ} \mathrm{C}, 52^{\circ} \mathrm{C}, 58^{\circ} \mathrm{C}, 64^{\circ} \mathrm{C}, \\
\text { and } 70^{\circ} \mathrm{C}\end{array}$ \\
\hline Ageing condition & $\begin{array}{l}\text { Un-aged, RTFOT-aged, and } \\
\text { PAV-aged }\end{array}$ \\
\hline
\end{tabular}

The variants (dependent variables) included were rheological characteristics of bitumen which consisted of $G^{*}, \delta, G^{\prime}, G^{\prime}$, and $G^{*} / \sin [\delta]$. However, only $G^{*}$ and $\delta$ were used in the ANOVA because the remaining variants were derivatives of $\mathrm{G}^{*}$ and $\delta$. The variants included in the regression analysis were G', G', and $\mathrm{G}^{*} / \sin [\delta]$. These three variants were directly related to the bituminous mixture performance.

\section{Findings and Discussion}

The data analysis results by factorial strip plot design are shown in Table 5 and 6. In the ANOVA, the null hypothesis $\left(\mathrm{H}_{0)}\right.$ stated that the source of variant does not yield any significant effect, and the alternative hypothesis $\left(\mathrm{H}_{1}\right)$ hypothesis stated that the source of variant provides some significant effects. At 95\% confidence level, the critical point of significant value $(\alpha)$ is 0.05 . In this case, $H_{0}$ is to be rejected if the significant value is less than 0.05 , and $\mathrm{H}_{0}$ is to be accepted if the significant value is higher than 0.05 .

The study found that the source of resins had a significant value of 0.065 or larger than the critical point value of 0.05 . This means that there was no significant difference of effect obtained from either the Buton rock asphalt or petroleum bitumen experiments with the complex shear modulus $G^{*}$. Meanwhile, the other factors were found to have a significant value less than 0.05 , meaning that there was a different effect caused by the different value of $\mathrm{G}^{*}$

Table 5. The Analysis of Variants of the Effect of The Resins Fractions on Complex Shear Modulus ( $\left.\mathrm{G}^{*}\right)$

\begin{tabular}{|c|c|c|c|c|c|}
\hline $\begin{array}{c}\text { Source of } \\
\text { variant }\end{array}$ & df & $\begin{array}{c}\text { Type III } \\
\text { Sum of } \\
\text { Squares }\end{array}$ & $\begin{array}{c}\text { Mean } \\
\text { Square }\end{array}$ & F & $\begin{array}{c}\text { Signifi } \\
\text { cant }\end{array}$ \\
\hline $\begin{array}{c}\text { Sources of } \\
\text { resins }\end{array}$ & 1 & 0.056 & 0.056 & 3.403 & $0.065^{*)}$ \\
\hline $\begin{array}{c}\text { Percentage } \\
\text { of resins }\end{array}$ & 2 & 11.035 & 5.518 & 336.463 & 0.000 \\
\hline $\begin{array}{c}\text { Test } \\
\text { temperature }\end{array}$ & 7 & 3369.036 & 481.291 & $\begin{array}{c}29348.81 \\
0\end{array}$ & 0.000 \\
\hline $\begin{array}{c}\text { Aging } \\
\text { condition }\end{array}$ & 2 & 548.274 & 274.137 & $\begin{array}{c}16716.69 \\
2\end{array}$ & 0.000 \\
\hline Error & 1212 & 19.876 & 0.016 & & \\
\hline Total & 1231 & 120980.845 & & & \\
\hline
\end{tabular}


Note: *)Not Significant

Table 6. The Analysis of Variants Results of the Effect of the Resins Fractions on Phase Angle ( $\delta$ )

\begin{tabular}{|l|c|c|c|c|c|}
\hline $\begin{array}{c}\text { Source of } \\
\text { variant }\end{array}$ & df & $\begin{array}{c}\text { Type III } \\
\text { Sum of } \\
\text { Squares }\end{array}$ & $\begin{array}{c}\text { Mean } \\
\text { Square }\end{array}$ & F & Significant \\
\hline $\begin{array}{l}\text { Sources of } \\
\text { resins }\end{array}$ & 1 & 2290 & 2290 & 0.391 & $\left.0.532^{*}\right)$ \\
\hline $\begin{array}{l}\text { Percentage } \\
\text { of resins }\end{array}$ & 2 & 219.845 & 109.923 & 17.768 & 0.000 \\
\hline $\begin{array}{l}\text { Test } \\
\text { temperature }\end{array}$ & 7 & 178588.6 & $\begin{array}{c}25512.65 \\
7\end{array}$ & $\begin{array}{c}4356.0 \\
8\end{array}$ & 0.000 \\
\hline $\begin{array}{l}\text { Aging } \\
\text { condition }\end{array}$ & 2 & $\begin{array}{c}37080.16 \\
7\end{array}$ & $\begin{array}{c}18540.08 \\
4\end{array}$ & $\begin{array}{c}3165.5 \\
7\end{array}$ & 0.000 \\
\hline Error & 1224 & 7168.713 & 5.857 & & \\
\hline Total & 1243 & $\begin{array}{c}6872621 \\
135\end{array}$ & & & \\
\hline
\end{tabular}

Note: ${ }^{*}$ Not significant

Table 6 describes all sources of variants, except for the source of resins which significantly influenced the phase angel.

Because there was no effect produced from the source of resins factors, this variable of sources was excluded in the regression analysis. Therefore, the selected independent variables were the percentages of resins, testing temperature levels, and ageing conditions. These variables were regressed to dependent variables which consisted of $\mathrm{G}^{\prime}, \mathrm{G}^{\prime}$, and $\mathrm{G}^{*} / \sin [\delta]$.

The results yielded the exponential regression model of resins content with bitumen rheological characteristics. The model was transformed into a linear model by expressing the bitumen rheological characteristics in the natural logarithmic values. The regression model is shown in Equation 1 below.

$$
\operatorname{LnY}=\mathrm{a} \mathrm{X}_{1}+\mathrm{bX}_{2}+\mathrm{c}
$$

Where: $\mathrm{Y}=$ rheological characteristics; $\mathrm{X}_{1}=$ percentage of resins; $X_{2}=$ temperature level; $a$, $\mathrm{b}$, and $\mathrm{c}=$ coefficient of $\mathrm{X}_{1}, \mathrm{X}_{2}$, and Constant.

The model was statistically analysed by involving two indicators, namely:

(i) Significant level of regression, and

(ii) Coefficient determination of regression (R).

The significant level of regression indicated the probability that the functional relationships were real. The significant value of regression less than 0.05 indicated the $95 \%$ chance that the relationship exists. The coefficient of determination $\left(\mathrm{R}^{2}\right)$ shows how well a regression model fits the data. It represents the percentage of variations that could be explained by the regression equations. The the regression model analysis results of the resins content on bitumen rheological at different levels of ageing are shown in Table 7.
Table 7 Analysis of the Regression Model of the Resins Content (Extracted Based on Corbatt Method) on Bitumen Rheology

\begin{tabular}{|c|c|c|c|c|c|}
\hline $\begin{array}{c}\text { Rheological } \\
\text { Characteristics } \\
\text { (Y) }\end{array}$ & $\mathbf{R}$ & $\mathbf{a}$ & b & c & $\begin{array}{c}\text { Significant } \\
\text { of } \\
\text { Regression }\end{array}$ \\
\hline \multicolumn{6}{|c|}{ Un-aged Condition : } \\
\hline Ln G' & 0.994 & 0.004 & -0.198 & $\begin{array}{c}16.67 \\
6 \\
\end{array}$ & 0.000 \\
\hline Ln G” & 0.996 & 0.003 & -0.140 & $\begin{array}{c}16.11 \\
2\end{array}$ & 0.000 \\
\hline $\operatorname{Ln}\left(\mathrm{G}^{*} / \sin [\delta]\right)$ & 0.996 & 0.003 & -0.141 & $\begin{array}{c}16.15 \\
9\end{array}$ & 0.000 \\
\hline \multicolumn{6}{|c|}{ Short Term Aging (after TFOT) Condition : } \\
\hline Ln G' & 0.991 & 0.041 & -0.190 & $\begin{array}{c}17.65 \\
6\end{array}$ & 0.000 \\
\hline Ln G” & 0.996 & 0.049 & -0.133 & $\begin{array}{c}16.38 \\
2 \\
\end{array}$ & 0.000 \\
\hline $\operatorname{Ln}\left(\mathrm{G}^{*} / \sin [\delta]\right)$ & 0.996 & 0.049 & -0.116 & $\begin{array}{c}16.54 \\
1\end{array}$ & 0.000 \\
\hline \multicolumn{6}{|c|}{ Long Term Aging (after PAV) Condition : } \\
\hline Ln G' & 0.998 & 0.047 & -0.163 & $\begin{array}{c}17.80 \\
6\end{array}$ & 0.000 \\
\hline Ln G” & 0.997 & 0.063 & -0.116 & $\begin{array}{c}16.25 \\
9 \\
\end{array}$ & 0.000 \\
\hline $\operatorname{Ln}\left(\mathrm{G}^{*} / \sin [\delta]\right)$ & 0.998 & 0.037 & -0.144 & $\begin{array}{c}17.96 \\
9\end{array}$ & 0.000 \\
\hline
\end{tabular}

Note: $\mathrm{Y}=$ rheological characteristics, $\mathrm{X}_{1}=$ percentage of resins, $\mathrm{X}_{2}=$ test temperature, $\mathrm{a}=$ coefficient of $\mathrm{X}_{1}, \mathrm{~b}=$ coefficient of $\mathrm{X}_{2}, \mathrm{c}=$ Constant

Table 7 shows that all of the determination coefficients at un-aged, RTFOT aged, and PAV aged; were all in the range of 0.991 to 0.998 . The regression models explained the relationship between the rheology of bitumen and its resins content quite accurately. Furthermore, all of the significant regression values indicate that the functional relationships of the regression models are real.

The treatment effect coefficient of resins in the regression equations on the bitumen rheology is shown in Figure 2.

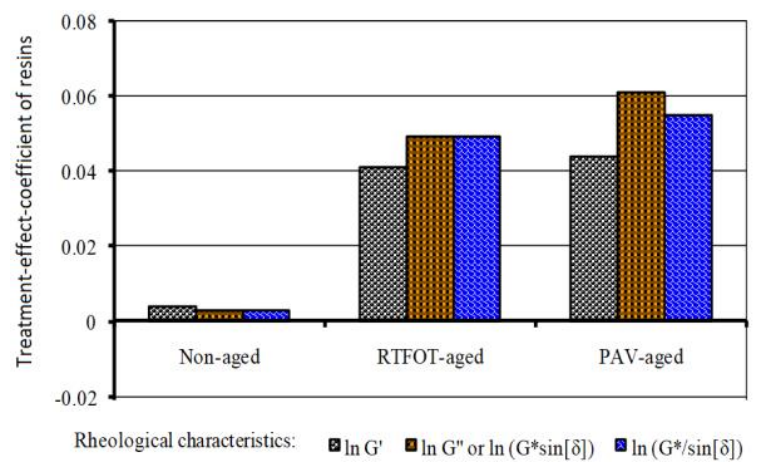

Fig 2. The treatment effect coefficient of resins in the regression equations

The result shows, at fresh condition, that there was no effect of adding resins on the bitumen rheological characteristics except for the elastic modulus (G'). However, the effect increased over the RTFOT-ageing 
and PAV-ageing rates because of the normal ageing process.

The effect of the test temperature on the rheological characteristics at various level of ageing was compared and presented in Figure 3.

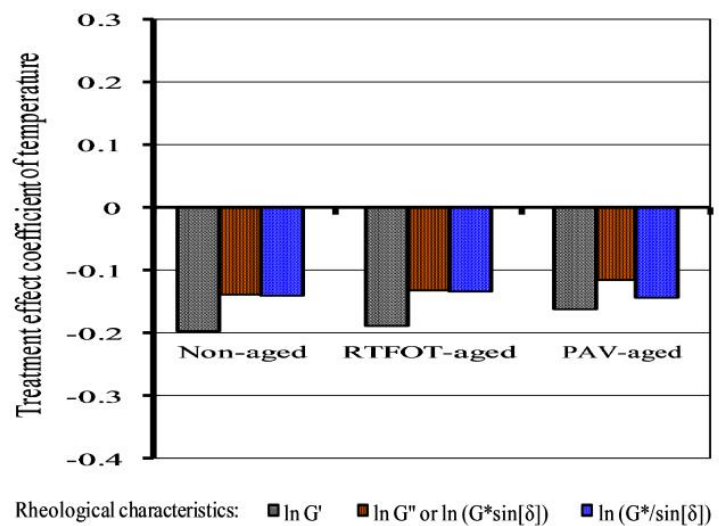

Fig 3. The treatment-effect-coefficient of temperature in the regression equations

The result indicated that there was an effect of the test temperature on the bitumen rheological characteristics of the samples containing the resins produced by Corbett extraction methods. It was also found that the treatment-effect-coefficient of the test temperature on bitumen rheological characteristics at each of the ageing conditions was shown to be negative. In other words, as the temperature level increased, the bitumen rheological characteristics decreased. Furthermore, the absolute value of the treatment-effectcoefficient of the test temperature on the elastic modulus was higher than the viscous modulus leading to a conclusion that the temperature of increment affected the elastic modulus more than the viscous modulus. Figure 3 also demonstrates that at a long-term ageing condition bitumen became less susceptible to temperature.

The constant of the regression equations based on both Corbett fractionation methods presented and compared is as exhibited in Figure 4.

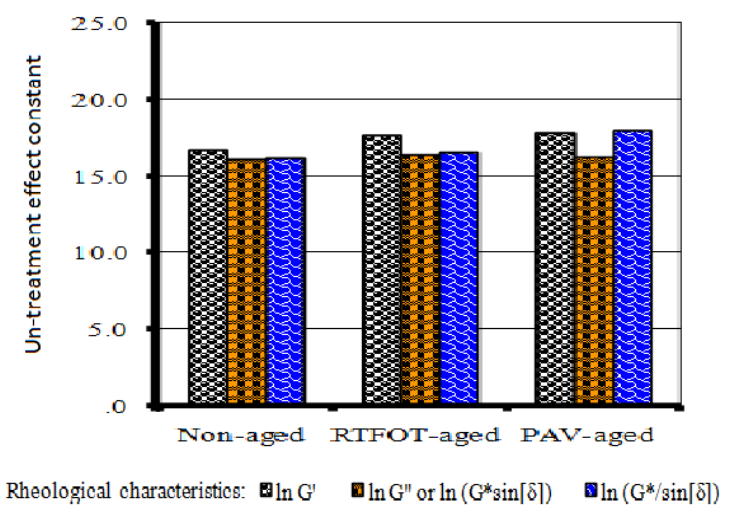

Fig 4. The un-treatment effect coefficient in the regression equations

The un-treatment effect coefficient constant indicated the rheological characteristics of the bitumen medium used in the experiment. As mentioned earlier, the experiment used the same petroleum bitumen sample therefore it is imperative that the un-treatmenteffect-coefficient constant between the two regression equation models was relatively similar as shown in Figure 4.

Ageing characteristics of bitumen can be identified by its ageing index (AI) which is defined as the ratio of a bitumen chemical or rheological parameter after and before the ageing [6] [7]. The ageing index is determined based on rheological characteristics which is calculated by the following equations.

$$
\mathrm{AI}=\frac{(\text { Aged bitumen rheology) }}{(\text { Unaged bitumen rheology) }}
$$

$\ln \mathrm{AI}=\ln ($ Aged bitumen rheology) $-\ln$

(Unaged bitumen rheology)

In this study, the contribution of resins fraction on bitumen ageing index was calculated by substituting Equation 3 into Equation 4 or Equation 5 as follows.

$\ln \mathrm{AI}=\left(\mathrm{aX} \mathrm{X}_{1}+\mathrm{bX} \mathrm{X}_{2}+\mathrm{C}\right)_{\text {aged }}-\left(\mathrm{aX} \mathrm{X}_{1}+\mathrm{bX} \mathrm{X}_{2}+\mathrm{C}\right)_{\text {unaged }}$

or,

$\ln \mathrm{AI}=\left(\mathrm{a}_{\text {aged }}-\mathrm{a}_{\text {unaged }}\right) \mathrm{X}_{1}+\left(\mathrm{b}_{\text {aged }}-\mathrm{b}_{\text {unaged }}\right) \mathrm{X}_{2}+\left(\mathrm{c}_{\text {aged }}-\mathrm{c}_{\text {unaged }}\right)$

The ageing indices were later differentiated based on the ageing level of as short and long term ageing indices. each of the ageing index for $G^{\prime}, G^{\prime \prime}$, and $G^{*} / \sin [\delta]$ is shown in Figures 4 to 7 . The results indicated that the increment of resins increased ln AI. Next, the PAV aged bitumen produced a higher Ageing Index than the RTFOT aged bitumen.

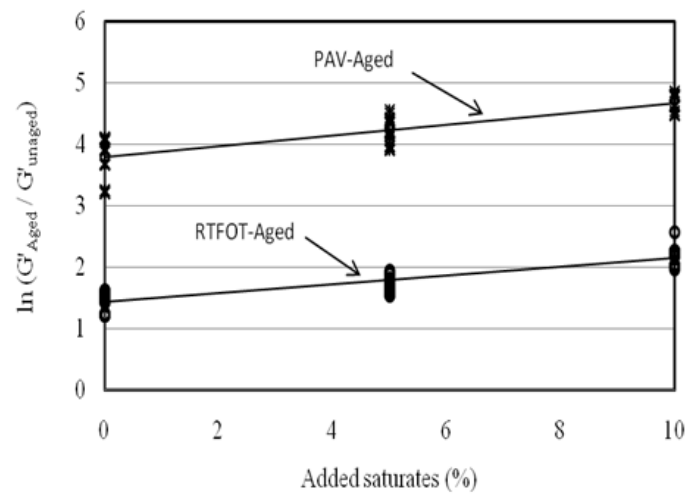

Fig. 5 Logarithmic Aging Index for G' of the blended bitumen 


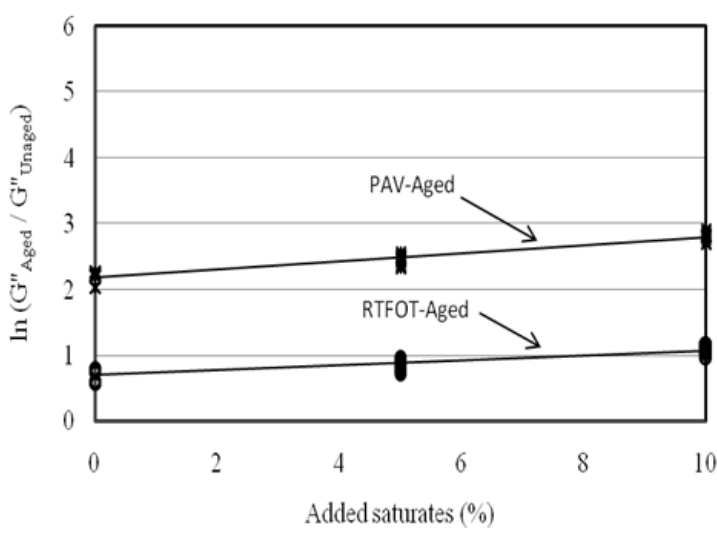

Fig. 6 Logarithmic Aging Index for G" of the blended bitumen

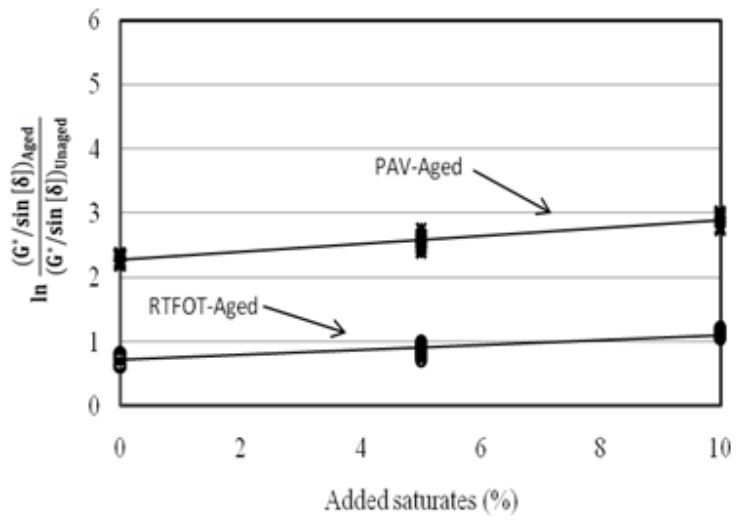

Fig. 7 Logarithmic Aging Index for $\mathrm{G}^{*} / \sin [\delta]$ of the blended bitumen

With reference to Equation 5, the contribution of resins on $\ln \mathrm{AI}$ is defined as $\left(\mathrm{a}_{\text {aged }}-\mathrm{a}_{\text {unged }}\right)$ and the results are as shown in Table VIII. Only extracted resins based on the Corbett method are considered and presented.

\section{Conclusion}

The results indicated that the source of resins had a significant value of 0.065 or larger than the 0.05 critical point value. There was no difference in the effect of the results of the experiments from either the Buton rock asphalt or petroleum bitumen on the complex shear modulus $G^{*}$. Meanwhile, the other factors had some significant values less than 0.05 meaning that the different factors were caused by the different values of $\mathrm{G}^{*}$. At fresh condition, there was no effect of adding resins on the bitumen rheological characteristics except for the elastic modulus (G'). However, the effect increased over the RTFOT-ageing and PAV-aging because of the normal ageing process.

This study is part of the research work on the new chemical durability indices of bitumen based on rheological and ageing characteristics. The research was carried out at the University Tunn Hussein Onn Malaysia and was supported by The Centre for Research and Development of Road and Bridge of the Ministry of Public Work and Housing of Indonesia.

\section{References}

[1] R. E. Boyer, "Asphalt Rejuvenators ' Fact or Fable' (Book style)", Asphalt Institute, Transportation Systems 2000 (TS2K) Workshop, San Antonio Texas, 2000.

[2] D. Lesueur, "The colloidal structure of bitumen: consequences on the rheology and on the mechanisms of bitumen modification.," Elsevier Advances in colloid and interface science, vol. 145, no. 1-2, pp. 42-82, Jan. 2009.

[3] J. C. Petersen, "A Review of the Fundamentals of Asphalt Oxidation, Chemical, Physicochemical, Physical Property, and Durability Relationships", Transportation Research Circular E-C140. Transportation Research Board, Washington DC, 2009.

[4] Roberts, F. L., Kandhal, Prithvi, S., Brown, E.Ray, Lee, Dah-Yinn, Kennedy, Thomas W., "Hot Mix Asphalt Materials, Mixture Design and Construction (Book style)", NAPA Education Foundation, Lanham, MD, 1996.

[5] P. Michalica, P. Daucik, and L. Zanzotto, "Monitoring of Compositional Changes Occuring During the Oxidative Aging of Two Selected Asphalts from Different Sources", Petroleum and Coal vol. 50 no. 2, pp. 1-10, 2008.

[6] A. Demirbas, "Asphaltene yields from five types of fuels via different methods.pdf," Elsevier Energy Conversion and Management, vol. 43, pp. 10911097, 2002.

[7] K. K. Kumar and A. Veeraragavan, "Optimizing the Bituminous Concrete Mixes for Fatigue Performance," The Open Construction and Building Technology Journal Vol. 2, Bentham Science Publishers Ltd. pp. 53-58, 2008.

[8] Hardee, J. R., (2004), Physical and Chemical Characteristics of Superpave Binders Containing Air Blown Asphalt, Henderson State University Arkansas: Final Report MBTC 2049.

[9] Hermadi, M., Zamhari, K. A., Karim, A. T. A., Abdullah, M. E., and Lloyd, L. L. "The Effect of Saturates on Rheological and Aging Characteristics of Bitumen" International Science Index, International Journal of Vol:6 No: 12, 2012.

[10] American Standard Testing Materials, 2011, "Standard Test Method for Separation of Asphalt into Four Fractions", ASTM D4124-09, 2011 Annual Book of ASTM Standards, West Conshohocken: ASTM.

[11] American Standard Testing Materials, 2011, "Standard Test Methods for Quantitative Extraction of Bitumen From Bituminous Paving Mixtures", ASTM D2172-01, 2011 Annual Book of ASTM Standards, West Conshohocken: ASTM.

[12] American Standard Testing Materials, 2011, "Standard Practice for Recovery of Asphalt from Solution Using the Rotary Evaporator", ASTM D5404-01, 2011 Annual Book of ASTM Standards, West Conshohocken: ASTM. 
[13] American Standard Testing Materials, 2015, Standard Specification for Performance Graded Asphalt Binder, ASTM D6373-15, 2015 Annual Book of ASTM Standards, West Conshohocken: ASTM.

[14] American Standard Testing Materials, 2011, "Standard Test Method for Determining the Rheological Properties of Asphalt Binder Using a Dynamic Shear Rheometer", ASTM D7175-08, 2011 Annual Book of ASTM Standards, West Conshohocken: ASTM.

[15] American Standard Testing Materials, 2011, "Standard Test Method for Effect of Heat and Air on a Moving Film of Asphalt (Rolling Thin-Film Oven Test)", ASTM D2872-08, 2011 Annual Book of ASTM Standards, West Conshohocken: ASTM.
[16] American Standard Testing Materials, 2011, "Standard Practice for Accelerated Aging of Asphalt Binder Using a Pressurized Aging Vessel (PAV)", ASTM D6521-08, 2011 Annual Book of ASTM Standards, West Conshohocken: ASTM. 